\title{
Teachers' Oversight of Science Values That Promotes Effective Citizenship
}

\author{
Omilani Nathaniel A. ${ }^{1}$, Ayo-Vaughan Adewunmi F. ${ }^{2}$, Abimbade Oluwadara A. ${ }^{3}$ \\ ${ }^{1}$ Department of Integrated Science, Federal College of Education, Abeokuta, Nigeria \\ ${ }^{2}$ Department of Curriculum \& Instruction, Federal College of Education (Technical), Asaba, Nigeria \\ ${ }^{3}$ Department of Teacher Education, University of Ibadan, Ibadan, Nigeria
}

Email address:

ayonath2002@yahoo.com.au (Omilani N. A.)

\section{To cite this article:}

Omilani Nathaniel A., Ayo-Vaughan Adewunmi F., Abimbade Oluwadara A. Teachers' Oversight of Science Values That Promotes Effective Citizenship. International Journal of Education, Culture and Society. Vol. 2, No. 3, 2017, pp. 88-93. doi: 10.11648/j.ijecs.20170203.12

Received: August 6, 2016; Accepted: September 29, 2016; Published: April 14, 2017

\begin{abstract}
Science and technology is the backbone of development of any nation. It provides the necessary training for development of scientific skills and literacy in citizen. Science education in Nigeria also aims to cultivate a rational mind for the conduct of a good life and democracy. A careful analysis of the entire content of the science curriculum shows that this objective of science education which is value oriented appears not to receive adequate attention. This is because science teachers emphasize skills and knowledge acquisition than they do for value acquisition. This study highlights some science values and attitudes, some events in the science practical as well as the opportunity these events provide the teacher to teach values. This study also shows the similarity between some controversial and unexpected occurrences during science practical and current national challenges. Values of effective citizenship in social studies were also related to science values that can promote development and peace in the Nigerian state.
\end{abstract}

Keywords: Democracy, Science, Citizenship, Peace and Practical

\section{Introduction}

Education is necessarily concerned with impartation of knowledge and inculcation of skills to prepare people for work in adult life and above all helping young people develop as full human beings inclined and equipped to lead the good life rather than the bad [1]. Education is primarily concerned with the transmission of social values [2]. The school therefore is an instrument of the society which should serve in achieving this objective. This is essential because the student is not merely an individual outside of the society rather he has right and duties towards others as well as the community, nation and the world at large. Therefore every teacher irrespective of his or her discipline is expected to accept the responsibility that the teaching of values like integrity, national thinking, sound judgment and social responsibility in his or her subject are not overlooked.

The goal of science education according to Nigeria's National Policy of Education is:

Cultivate inquiring, knowing and rational mind for the conduct of a good life and democracy; produce scientist for national development service; studies in technology and cause technological development and provide knowledge and understanding of the complexity of the physical world, the forms and the conduct of life (pg 29) [3].

A careful analysis of the entire content of the science curriculum shows that the first objective of science education (a rational mind for the conduct of a good life and democracy) which is value oriented is not reflected in any topic like we have in social studies and civic education curricula. This has resulted in teachers' focus on science education producing future scientist and technologist that will drive the economy but overlooking latent possibility of science education developing effective citizen that will contribute meaningfully to the democratic process. Science in itself is not only an accumulated and systematized learning restricted to natural phenomenon as scientist also have values and attitudes that guide their conduct. The knowledge of science is important in making crucial decisions on everyday issues and problems, and also in the making of informed citizens who are capable of taking personal actions to find solutions to any identified issues and problems [4], [5]. 
Science is indispensable for generating knowledge, identifying new societal problems and outlining alternative solutions [6]. Thus, science and technology affects not only economic prosperity but also transforms the social structures, modes of behaviours, attitudes of the mind and the level of tolerance which improvement in education will bring [7], [9]. If science education which is the mother of science and technology promotes this kind of social change, peace building process will be strengthened.

Most of the violent conflicts in the world today are low intensity conflict rooted in racial, ethnic and religious hatred combined with structural cleavages and political oppression that result in the victimization of one or more groups through the denial of their fundamental needs [7]. In the continent of Africa countries like Sierra lone, Liberia, Cote d' Ivoire, Guinea, Uganda, Somalia, Congo DR, Congo, Angola, Senegal and Nigeria are examples of places which had experienced or are currently experiencing various forms conflict. The recent Boko Haram insurrection in Nigeria is still a major contender of national peace. Most conflict in Africa to poverty, inequitable distribution of wealth, denial of human right, absence of rule of law arising from weak judicial system and religious intolerance [7]. Undeniably Africa and Nigeria in particular is faced with several value and ethical problems but finding solutions to all these problems forms the hallmark of the introduction of social studies into the Nigerian curriculum.

The introduction of social studies as an integrated subject into the Nigerian curriculum was premised on the need to cultivate in people the right code of conduct and good citizenship in public and private lives [10]. Similarly, the civic education curriculum is capable of promoting civic competence. Thus, most peace building programmes in education have concentrated on subjects like civic education and social studies as these subjects seem to place more emphasis on values acquisition than other subject in the school curriculum [10]. Scientific knowledge can be used in peace building, most especially knowledge acquired through a process of experimentation and observation [7], [11]. This therefore place emphasis on values acquisition in the teaching of science.

The teaching of attitude and values in science is usually not emphasized because it is not stated black and white in the curriculum. Attitudes as mental disposition towards people objects, subjects, events [12]. In addition, attitude as a way of behaving that is learnt which compels the individual to manifest particular actions towards a particular person, object or condition [13]. The entrenchment of science attitude in the teaching - learning process is a gradual thing and becomes more pronounced during science practicals. Science attitudes are dynamic results of experience that act as a directive factor when a child enters into new experiences [14].

The attitudes science education inculcates in students at any level carry emotional and intellectual tones both of which lead to decision making and formulating evaluation [12]. Most of these attitudes are essential for human existence and democratic progress. Scientific attitude include : humility skepticism, logical reasoning, intellectual honesty, open-mindedness, suspending judgment, positive approach to failure, empiricism, determinism, patrimony, precision, respect for paradigms, empathy for human conditions, understanding that all knowledge has tolerance limits, appreciation of probability and statistics and respect for power of theoretical structure to mention a few. These science attitudes are closely connected to the attitudes expected to be developed in social studies which are: developing a capacity to learn and to acquire certain basic skills including not only those of listening, speaking, reading and writing and of calculation but also those skills of hand and head, together with those of observation, analysis and inference which are essential to the forming of sound social, economic and political judgment; developing, in students, positive attitudes of togetherness, comradeship and cooperation towards a healthy nation; the inculcation of appropriate values of honesty, integrity, hard work, fairness and justice at work and play as one's contribution to the development of the national goal [14], [8], [15], [16].

Unfortunately, science teachers hardly appreciate and recognize the difference between science in the making and readymade science. Science in the making is very controversial [17]. On the other hand the ready-made science is the unproblematic science that is usually described in the science textbook. In an attempt to affirm the unproblematic science of the textbook during classroom instruction students are denied the opportunity to inculcate the attitudes and values that science promotes by teachers. When students are not provided with the experience of the controversy that accompanies science in the making, they will receive a wrong message about the nature of science [18]. This wrong message he called conflict of epistemology of the curriculum planner who wants the teacher to train the future scientist and the positive laden practical classroom which does not allow students to see science as a holistic entity. For example when science teachers observe that science practicals do not go the way of the ready-made science, they chase the right answer by all means, instead of upholding values like intellectual honesty and suspended judgment. Below are some hypothetical instances of science experiments that went and the actual teachers response [19].

\section{Instance}

A class of year one are heating Magnesium ribbon in a crucible with a lid. The purpose of the lesson is to test a consequence of oxygen theory that material gain weight when burnt. During the summary at the end of the lesson, four groups reported a loss in weight, two groups reported no difference while two groups reported a gain in weight.

Teachers response

They need to make sure that everybody followed the same procedure

Experiment don't always work (fit accepted theory)

That if experiment don't work they need to be critically evaluated

That result can be averaged and/or discounted

Some teachers demonstrated knowledge about the 
procedures that scientist use to check experimental results and that experiments are as much the results of the experimenter in their response.

Instance Interview

You have set up a demonstration of the production of oxygen by photosynthesis with Canadian pond weed. Just before the lesson when the class are to look at the apparatus again you notice that there is a small amount of gas in the test tube but not enough with which to do the oxygen test. List the kinds of things you could say and do before or during the lesson.

\section{Responses}

Teacher says and do things like: explaining why it doesn't work e.g. lack of light intensity. Teacher invoke auxiliary theories

Tweak the experiment e.g. increase the light intensity; add sodium bicarbonate to the water.

Cheat e.g. add oxygen from a tank prior to the lesson

From the responses, most teachers will demonstrate either the norm of criticality e.g. use of auxiliary theories and /or evaluation of the experimental set up so that the discrepancy explained, or teachers can use counter norms which are fraudulent.

Teachers often forget that controversial observations that are deviations from existing knowledge during experiments are great assets for the practicing scientist because it allows for ground breaking discoveries in terms of experimental procedure and products of science.

Mpemba effect which has been a source of research in physical science started in 1963 when a female Tanzanian secondary school student observed that hot water freezes faster than cold water. By the time she reported the observation both students and teachers despised the report because common sense and existing scientific knowledge disapprove her observation. At a point this student met with Dr Denis Osborne, she informed him about her findings. Dr Osborne repeated the experiment and found out it was true. As a result of the confirmation of the practicing scientist (Dr Osborne) the finding was published. This was named after the secondary school student. There are many observations of such magnitude buried in the conscience of students and teachers because they assume it will not earn them good marks or cause controversy because it is not in line with textbook science.

Teaching should embody the specific characteristics of the discipline it represents. One of the specific characteristics of science is positive approach to failure. This attitude make scientist to view failure as a step along a path in research [20]. Therefore scientists interpret failure as an addition to great store house of cumulative scientific information [21]. It is very crucial to inculcate scientific attitude in students during science lesson when opportunity provides itself. Teachers must remember that at their roots, science and democracy share same values. Democratic societies are founded on open debate, free flow of information, mutual respect and critical role enquiry and evidence [6] [22].

\section{Relationship Between Social Studies and Science Education}

The synergy between social studies and science education creates a notion that makes 'citizenship a living practice in which students actively engage in social issues in the society' [23]. The understanding of this synergy made science educators in America to embark on a new approach to science education called Science, Technology, Society and Environment Education (STSE). This approach underscores the need to examine the relationships between socio-cultural issues, economic uncertainties, technology development and the nature of science.

STSE is an aspect of science education that stimulate students to participate in scientific inquiry that affects humankind and make responsible decisions that may arise from such inquiry [24]. Encouraging responsible values and effective citizenship in and through science education is considered paramount in making science more meaningful to learners and will make them engage actively in societal issues. [25]. The intersection between these two bodies of knowledge is important to develop a multidisciplinary or 'multidimensional' citizen [23]. A multidimensional citizen is a student grounded in scientific facts and have positive scientific attitude and literacy, which are cultural, utilitarian, democratic and economic [26]. Also, the concept connotes making correct and informed decisions when embarking on scientific quest.

The interplay between social studies and science education create a dynamic relationship that can demystify various contentious concepts in both disciplines and ensure all students are able to develop skills and construct knowledge needed to live positively in the world. The domain of science education which promote responsible scientific attitudes brings to bear the whole realm of social studies which is to 'develop students that are better equipped to interact effectively and meaningfully in the environment, to produce good and effective citizens and develop competencies to become functional members of the society' [27].

Jeff Passe explains that when we teach students about pioneers (technological innovations and inventions, scientific discoveries), we are also making a value decision, he said;

"we may communicate to the students that we admire the courage, ingenuity, creativity, perseverance, and the desire for freedom of these pioneers". But, we must also allow students to conclude that some pioneers were greedy, overindividualistic, or even abusive to their families. Students who engage in this kind of discussion will have multiple perspectives and learn to tolerate difference of opinion. What could be better preparation for democracy? [28].

\section{An Overview of These Scientific Attitudes That Promotes Effective Citizenship}

\subsection{Humility}

Humility is simply freedom from pride and arrogance. 
Humility comes to scientist partly as a result of his exposure to ever-broadening horizons from his observations of human beings and the ways in which they tend to behave [21]. This makes the scientist not to play god and makes him to subject his or her findings to peer review. Science teachers therefore can make use of group activities and experiments to engender humility in students. Each group result is subjected to constructive criticism. The groups must have balanced gender and ethnic representations so as to ensure that gender and ethnic sensitivity which contributes to social justice. Taking this into consideration helps develop the learners' ability to make sound judgment.

\subsection{Empiricism}

A scientist prefers to look and see. Scientists do not argue about whether it is raining outside. All one needs to do is to stick a hand out the window. Underlying this is the belief that there is one real world following constant rules in nature that we can probe that real world and build our understanding. In a science classroom, during instruction, the teacher could take the advantage of using the events where students use biased theory to establish a fact or concept. The teacher on the other hand will ask empirical questions and give tasks that will make the learner to objectively reflect on his or her biased theory and see the faults there in. Students will be able construct empirical knowledge after such interaction. This can be extended and translated into effective citizenship considering the wrong notion students have about the workings of democratic system and certain cultures. Student will know that he has to go beyond initial bias and investigate before concluding

\subsection{Determinism}

Science believes that cause and effect underlie everything. In simple mechanisms, an action causes a reaction and effects do not occur without causes. Although, some processes are random or chaotic, but science believes that a causative agent do not constantly produce the same effect. Nigerian citizen often ridicule some approach to solving certain problems because of the antecedence of such approach. They assume they know the end result even before the initiating the process. The current national conference is a typical example. The citizens perhaps must have seen several editions but it does not mean that the current one will end like the previous ones. This gives scientist the belief that problems have solution. Major problems have been solved and tackled in the past.

In the early nineteen century typhoid was a terminal disease; there was no attempt to go into the space and in vitro fertilization was not discovered to mention a few. Any time science classroom discussion touches new scientific innovations and inventions, the science teacher can make the learners realize that it took optimism and determination before the scientist could get to that level.

\subsection{Respect for Paradigms}

Paradigm is our overall understanding about how the world works. It is a complete overall view of a phenomenon, often lying upon some basic principles. Until experiments begin to uncover error in a paradigm, the paradigm informs all the decisions the scientist make. If a concept does not fit into the existing paradigm, scientist finds out if the new concept is flawed or if the paradigm must be altered. Phlogiston theory of combustion for example was jettisoned when the process of combustion was better understood. Respect for theoretical structure is an attitude that students can imbibe when teacher mention old and new nomenclatures of substances and animals. The teacher will make them understand the reason for the change in paradigm. The paradigm for democratic process is the rule of law and the constitution. Students who respect science paradigm will be able transfer the attitude to democratic process. They will be able to respect the rule of law and appreciate the constitution amendment procedures at any level.

\subsection{Intellectual Honesty}

Intellectual honesty entails all the commitment to integrity and personal responsibility. Intellectual honesty makes the scientist to uphold integrity when proposing, performing and reporting research, transparency in conflict of interest or potential conflict of interest. Judgment about a person's integrity are less about strict adherence to the rules of practice and are more about the disposition to be intellectually honest, accurate, and fair in the practice of science [29]. Ethics to the practicing scientist is taken seriously such that truthfulness and integrity are core element of research and scientific work during science practical when things do not go as desired, an opportunity has been provided for a teacher to build intellectual honesty in students. When a teacher engages in unethical practice such as sorting data and bending procedural rules, they send a wrong message to the learner [18]. Firstly, student may assume that science only involves a chase toward the right answer. Secondly, this may make students to transfer fraudulent character into their everyday life and corruption will be the other of the day. Finally, the only scientists our education system will be able to produce are those who can only work in familiar terrain. As soon as things do not go by the book they will not be able to creatively design their way out.

\section{Conclusion}

Various studies have shown that there is problem with the democratic process in Nigeria which is expressed unscrupulous character and attitude people display [30]. In addition, specific values leaders are expected to possess if the democratic process will work out fine [31]. These are: being honest, being forward-looking, being competent, being inspiring, being intelligent, being fair-minded, being broadminded, being supportive, being straightforward, being dependable, being cooperative, being determined, being imaginative, being ambitious, being courageous, being caring, being mature, being loyal, being self-controlled, and being independent. The reflection of these values and 
attitudes cut across all subjects in the school curriculum. But how well attention is paid to their teaching is where the problem lies.

The current Nigerian democratic experience is about fourteen years old and it is the longest which is free of military interruption since independence. Most of those at the helm of affairs were born during military regime and have spent more than three-quarters of life observing wrong governance before they came to power. Therefore they are alien to democratic values which they should practice. Education has been suggested to be the best means of providing the coming generation with the proper way because this will make learners turn out to be citizen who will contribute meaningfully to the democratic process

It is also of essence to know that our journey toward democratic perfection is similar to the controversial science. Unfortunately what we expect as dividends of democracy is not what we currently experience. Social vices, inter-tribal war, corruption and economic challenges are indications that unlike textbook science where all the graphs are straight, our democracy is on a journey towards perfection. As it is said that no nation can rise above its level of education, one can also say that an educated being without values would not only have nothing sustainable to contribute to societal development but will even destroy that which has been built. Adequate acquisition of values brings positivism to the functional responsiveness of education.

\section{Recommendation}

It is therefore a recommendation of this paper that science teachers should place adequate emphasis on the teaching of values concepts embedded in the science curriculum. Also, scientific values observed in practical science classes should be adhered to. Science teachers should also build these values into their lesson plans by stating behavioural objectives that cover the affective domain of learning.

Schools therefore, should encourage and urge the teaching of core values and attitudes in science education.

Rudiments of history and philosophy of science should be taught at the undergraduate level so that pre-service science teacher will be aware of how the textbook science emerge.

Also, there must be effective mentoring, teachers must lead by example. They must not only teach the learners to uphold these values but also practice the same.

And lastly, the practice of these core values entrenched in social studies and science education must be the fundamental and first principles learners must learn in science education.

\section{References}

[1] Justa H. R. (1989) organization of guidance programme in schools. In Mascranahas M and Justa H. R. (ed) value education in schools and other essays. Delhi, Konark Publishers.

[2] Anameze, L. N. (2002). Remedying value conflict in young
Nigerian students via value development education. Journal of the Nigerian Society for Educational Psychologist. 1(1), 92100 .

[3] Federal Republic of Nigeria (2004). National Policy on Education. Revised Edition, Federal Government Press.

[4] Shamos, M. H. (1995). The myth of scientific literacy. New Brunswick, NJ: Rutgers University Press.

[5] Directorate-General for Research and Innovation (2015). SCIENCE EDUCATION for Responsible. Luxembourg: Publications Office of the European Union, Citizenship.

[6] Branscomb, L. M. and Rosenberg, A. A. (2012). Science and democracy. The Scientist Magazine.

[7] Massaquoi (2009). Strengthening peace building through science and technology education. Science Education International. 20 (1\&2).

[8] Ogunsanya, M. (1984). Introduction to methodologies of Social Studies. Ibadan: Evans (Nig) Publishers.

[9] ICSU (2011). Report of the ICSU Ad-hoc Review Panel on Science Education. International Council for Science, Paris.

[10] Jekayinfa, A. A, Mofoluwawo, E.O and Oladiran, M. A. (2012). Implementation of civic education curriculum in Nigeria. Challenges for social studies teachers.

[11] Chowdhury, M. (2016). Emphasizing Morals, Values, Ethics, and Character Education In Science Education And Science Teaching. The Malaysian Online Journal of Educational Science, Vol 4(2). Pp 1-16.

[12] Martin, R., Sexton, C., Franklin, T., Gerlovich and Mcelroy, D. (2010) Teaching Science for all Children (with my education Lab) New Jersey, Allyn and Bacon an Imprint of Pearson educational Inc.

[13] Kaya, H. (2011). Primary 6 grade students' attitude towards social studies lesson aided with Geographic Information System (GIS): Kaeabuk case. Middle-East Journal of Scientific Research. 7.3:401-406.

[14] Adaralegbe, A. (1980). The Nigeria social studies programme: Retrospect and Prospects. In N. E. R. C, Social Studies: Teaching Issues and Problems. Benin: Ethiope Publishing Corporation.

[15] Mansaray, A. (1991). TEE 141: Social studies methods. Department of Adult Education, University of Ibadan.

[16] National Council for the Social Studies (NCSS), (1992). Expectations of Excellence: Curriculum Standards for Social Studies (Washington, D.C.: NCSS, 1994): 3.

[17] Latour, B. (1987) Science in Action. Massachusetts, Harvard University Press.

[18] Allen, M. (2008) "Now this is what should have happened" A clash of epistemologies? EURASIA Journal of mathematics, science and technology education, 4: 4, 319-326.

[19] Nott, M. and Wellington, J (1996) When the black box springs open: practical work in schools and Nature of Science. International Journal of Science Education 18.7:807-818.

[20] Krischner, P. A. (1992) Epistemology, Practical work, and Academic skills in Science Education. Science Education, 1: 273-299. 
[21] Carin, A. A. and Sund, R. B. (1975) Teaching Modern Science. Ohio, Bell and Howell Company.

[22] Talisayon. V. M. (2000). Development of Scientific Skills and Values in Physics Education. Science Activities Classroom Projects and Curriculum Ideas. 37: 31-37.

[23] Richardson, G., \& Blades, D. (2001) Social Studies and Science Education: Developing World Citizenship Through Interdisciplinary Partnerships.

[24] Aikenhead, G. S. (2003) STS Education: a rose by any other name. In A Vision for Science Education: Responding to the world of Peter J. Fensham, (ed.) Cross, R.: Routledge Press.

[25] Aikenhead, G. S. (1994) What is STS science teaching? In Solomon, J. \& G. Aikenhead (eds.), STS Education: International Perspectives in Reform. New York: Teacher's College Press.

[26] Hodson, D. (2003) Time for action: Science education for an alternative future. International Journal of Science Education, 25 (6): pp. 645-670.
[27] Abimbade, O. A. (2015). Development of Mobile Learning Package and Training of Pre-Service Social Studies Teachers in Mobile Phones Usage as Teaching Support for Secondary Schools. Unpublished Ph.D Thesis.

[28] Passe. J. (1999). National Council for the Social Studies (NCSS), for National Congress for Public Education. http://www.socialstudies.org/system/files/publications/se/6302 /630212.html

[29] Institute of Medicine and National Research Council. (2002) Integrity in Scientific Research: Creating an Environment that Promotes Responsible Conduct. Washington, DC: The National Academies Press.

[30] Dike V. E. (2005). Values, education and national development. International Education Studies. Vol. 4, No. 1: Feb. 2011. Retrieved January 18, 2011 from http://www.ccsenet.org/ies

[31] Kouzes, and Posner. (2002). The leadership challenge. 3rd ed. Jossey-Bass. A Willey Coy. San Francisco, ca. In, Nigerian Institute of Management (Chartered) Journal. Vol. 46, No. 3, pp. 12. 